\title{
Title IX Compliance in NCAA Athletic Departments: Perceptions of Senior Woman Administrators
}

\author{
by \\ Robert C. Schneider ${ }^{1}$, William F. Stier Jr. ${ }^{2}$, \\ Timothy J. Henry 3 , Gregory E. Wilding ${ }^{4}$
}

\begin{abstract}
Perceptions of Senior Woman Administrators (SWAs) were sought regarding the equal provision of 13 Title IX compliance areas in women's athletic programs as compared to men's. A five point agree/disagree Likert-scale survey was electronically mailed to all SWAs at National Collegiate Athletic Association (NCAA) membership institutions throughout the United States. Of the 841 surveys mailed, 406 were returned for a $48.3 \%$ return rate. The SWAs disagreed or strongly disagreed at the highest rates that the following five Title IX compliance areas were being provided for equally in the women's programs when compared to the men's: publicity (31.0\%), locker room facilities $(27.1 \%)$, coaching $(20.0 \%)$, recruitment of student-athletes $(15.4 \%)$, and equipment and supplies (14.7\%). Significant differences between Likert-scale items of agreement/disagreement were found among the following SWA demographics: marital status, NCAA Division, years of experience, and reporting structure. The SWAs agreed or strongly agreed that the 13 Title IX compliance areas were being provided for equally in the women's programs when compared to the men's at the following rates: housing $\mathcal{E}$ dining facilities $(84.4 \%)$, medical $\mathcal{E}$ training facilities $(84.3 \%)$, scheduling of games $(81.1 \%)$, travel \& per diem allowances $(80.5 \%)$, practice facilities $(78.7 \%)$, competitive facilities $(78.4 \%)$, equipment and supplies $(77.7 \%)$, support services $(76.0 \%)$, tutoring $(74.3 \%)$, recruitment of student-athletes (73.2\%), coaching (70.3\%), locker room facilities (63.2\%), and publicity (55.3\%).
\end{abstract}

Key words: sex discrimination, equality, sport, survey

Achieving gender equity in intercollegiate athletic departments is an on-going challenge that requires constant attention. Although progress has been made since the inception of Title IX in 1972, close attention must always be paid to current inequities and the potential for future inequities of women's athletic programs when compared to men's. The status of gender equity in athletic de- partments is dynamic, which makes it necessary to consistently interpret Title IX's application to intercollegiate athletics (Cheslock \& Eckes, 2008), and to collect and report empirical data to accurately depict areas being provided for equally and those not being provided for equally. Accurately portraying intercollegiate athletic departments' compliance to areas of Title IX is necessary for the purpose of imple-

\footnotetext{
1 - Professor, Department of Kinesiology, Sport Studies, and Physical Education, The College at Brockport, SUNY, USA

2 - Distinguished Service Professor, Department of Kinesiology, Sport Studies, and Physical Education, The College at Brockport, SUNY, USA

3 - Associate Professor, Department of Kinesiology, Sport Studies, and Physical Education, The College at Brockport, SUNY

4 - Associate Professor, Department of Biostatistics, The State University of New York at Buffalo
} 
menting strategies to ensure equity between women's and men's intercollegiate athletic programs. Serving as one such resource to help accurately portray the extent to which Title IX compliance areas are being provided for equally between women's and men's athletic programs are Senior Woman Administrators (SWAs). The direct employment of SWAs in athletic departments allows for first hand perceptions relative to gender inequities between men's and women's athletic programs.

\section{Background Literature}

\section{Inception/History of Title IX}

Title IX was part of the Educational Amendments Act of 1972, and was the first major step toward achieving equity for women in sport programs. In the interest of equity achievement Title IX states that the following are illegal: discrimination, exclusion from participation, the denial of benefits, or the restriction of participation in programs or activities receiving federal assistance (U.S. Department of Labor, n.d.). Changes in the law, in many cases, limited Title IX's application to athletics until the Civil Rights Restoration Act of 1987 was passed by Congress in 1988. The Civil Rights Restoration Act of 1987 ensured that Title IX applies to all operations of a recipient of federal funds, which, in effect, allowed the Office of Civil Rights (OCR) to regain jurisdictions over athletics (Gender Equity, n.d.). More actively enforced beginning in the late 1990s rather than immediately after its inception in 1972, Title IX mandated that equal opportunities and accommodations be provided for both male and female athletes in sport (U.S. Supreme Court, 1984). The National Coalition for Girls and Women in Education (2008) not only chronicles the history of Title IX but also provides details pertaining to its progress, setbacks, and current status.

\section{Progress toward Equity/Title IX Compliance}

Since the passage of Title IX much progress has been made toward compliance and equity between women's and men's athletic programs (Acosta \& Carpenter, 2009; Kuznick \& Ryan, 2007; Vest \& Masterson, 2007). Opportunities for both men and women continue to increase and are higher than ever for women (Lipka, 2007). And one out of five athletics directors is a woman, the highest female representation since the mid-1970s (Acosta \& Carpenter).
Acosta and Carpenter also spoke of items that are not part of Title IX but are vital to accomplishing its spirit and serve as evidence that Title IX has arrived.

\section{Infractions/Violations}

Resistance, in some circles, to gender equity in athletic departments is a "constant" as is evident in the numerous Title IX infractions that have been formally documented since the law's establishment. Still today, one needs to not look far to identify abuses of the letter of the law and maybe more problematic the spirit of gender equity achievement, which is most important for the success of Title IX. Infractions range widely including but not limited to scheduling of women's sports in non-traditional seasons (Pittman, 2007), opportunities for women to play (Lipka \& Wolverton, 2007), the lack of upgrades in women's programs (Schachter, 2007), and retaliation against those raising Title IX complaints (Kuznick \& Ryan, 2007).

\section{Enforcement and Continued Resolve}

The numerous Title IX infractions spanning the period since its inception in 1972 to present indicate the importance of sustained enforcement for the continued effectiveness of Title IX. In the past, enforcement of Title IX has varied depending on national leadership (Sander, 2009). The tendency seems to be for a more aggressive enforcement under Democratic administrations and indications are that President Obama will devote more resources to the Education Department's Office for Civil Rights agency to support enforcement (Sander). Acosta and Carpenter (2009) spoke to the importance of "will" in attaining equity, especially the strength of the will in the offices of college athletic directors and president's offices. Without the resolve to consistently enforce Title IX compliance, the return to gender inequities that used to be the norm in athletic departments is probable.

\section{Challenges Confronting Female Administrators in Athletics and Beyond}

In a study that surveyed a sample of National Collegiate Athletic Association (NCAA) female athletic directors across all three divisions, Title IX issues were revealed as major challenges confronting female athletic directors (Dupreé, Willis, \& Pettaway, 2006). Further, gender discrimination, sexism in sport, and finding a balance between male and fe- 
male programs were revealed as challenges by the female athletic directors (Dupreé et al.). Title IX and in particular the budget/funding aspect of Title IX were identified through a survey of Division I female administrators as a challenge confronting female athletic directors at NCAA Division I institutions (Dupreé et al.). Also related to Title IX but specific to NCAA Division II, the good ole' boys network and personnel issues were identified as obstacles confronting female athletic directors (Dupreé et al.).

Females, according to Suggs (2000) are underrepresented in the upper athletic administration positions of intercollegiate sport organizations. Whisenant (2003) emphasized the lack of equality by pointing out that since the passage of Title IX, girls can play the games, but women are not allowed to control the games. Gender equity may exist in principle but not practice as Tiell (2005) indicated that Division III SWAs have multiple duties but many are not in a primary position considered to be part of the senior management team. Gaining access to management positions does not necessarily equate to actual decision making responsibilities. Women who gain access to management positions within Division I programs tend to be relegated to support positions such as assistant or associate athletic directors within the areas of academic advising, compliance, marketing, life skills, and sports information (Whisenant, Pedersen, \& Obenour, 2002).

The primary purpose of this study was to discover to what extent, based on the perceptions of SWAs, Title IX compliance areas are provided for equally in women's NCAA athletic departments as compared to men's. For the purpose of revealing differences within demographic criteria of the SWAs, their perceptions were also analyzed with respect to their marital status, NCAA Division, years of experience, and reporting structure.

Perceptions regarding equality between men's and women's programs related to Title IX compliance areas should not necessarily be the "end all" but should be considered as one source along with several approaches to measuring equality including but not limited to hard data related to the allocation of funds for programs. The perceptions of SWAs do, however, serve as a sound source that can be used to confirm the progress or lack thereof toward equality between women's and men's programs in NCAA athletic programs.

\section{Methods}

\section{Subjects}

Subjects consisted of all employees who held the title of SWA in all NCAA athletic departments throughout the United States. The SWA is the highest ranking female involved in the management of an NCAA institution's intercollegiate athletics program (NCAA Division I Manual 2008-09, 2008). Responsibilities of the SWA listed in the NCAA Senior Woman Administrator Brochure (as cited in Andrews-Little, 2006) included strategizing ways to manage Title IX plans and issues as well as gender equity. In the case of this national research study, SWAs in fact, are acutely aware of gender equities and inequities in athletic departments and thus serve as insightful subjects from which to ascertain perceptions.

\section{Questionnaire}

The list of Title IX compliance areas formally referred to in the NCAA Gender Equity Manual (n.d.) as "the laundry list" was the foundation from which the questionnaire was developed. Two outside experts in the areas of gender equity and Title IX confirmed the appropriateness of the content, helping to ensure for content validity, and also provided feedback relative to the format of the questionnaire.

A cover letter was electronically mailed to each SWA. Included in the cover letter were directions to self-administer the survey, and a hyperlink allowing for immediate access to the survey. It was made clear in the cover letter and adhered to throughout the study that participation of the SWAs was voluntary and not restricted on the basis of race, gender, age, or any other characteristics.

Anonymity of the SWAs and their institutions was preserved by creating an internal numeric code for each returned survey that was not linked to the subjects' email addresses. Confidentiality of all information provided, including responses, was maintained as it was stored in a secure location.

\section{Sample Size and Rate of Return}

At the time of the mailing, the total number of NCAA athletic departments, regardless of classification, was 1050. It can be assumed that each athletic department employs an SWA because the NCAA requires that its members fill the position of SWA. 
Electronic mail addresses were available on athletic department Websites for 841 SWAs; thus the sample size was 841 . Of the 841 SWAs who were e-mailed the link for the on-line survey, 406 returned the surveys for a $48.3 \%$ return rate. Anyone who has done survey research knows response rates are typically very low, often around $48 \%$ for mailed surveys (Ransdell, 1996) and between $27-32 \%$ for email surveys (Marks, 2005).

\section{Data Analysis}

To determine differences in the distribution of Likert-scale questions by demographic variables the Kruskal-Wallis rank test was used at a 0.05 nominal significance level. The calculation of frequencies and relative frequencies were used to summarize all variables and all analyses were performed using SAS version 9.1.3.

\section{Results}

Responses to demographic questions revealed that nearly all (99.7\%) of the 406 SWAs were females. Responses to additional demographic question indicated that $86.8 \%$ of the SWAs were Caucasian, $46.1 \%$ were married, $58.6 \%$ had no children, $74.8 \%$ had a master's degree, $20.9 \%$ made between $\$ 45,000$ $\$ 55,000$ per year, and $92.1 \%$ reported to the athletic director.

\section{Overall}

Displayed in Table 1.0 are the rates at which the SWAs agreed or disagreed that the 13 NCAA Title IX compliance areas were provided for equally in the
SWAs' women's athletic programs as compared to the men's athletic programs. After collapsing the categories of strongly disagree and disagree each compliance area was also ranked from 1 (highest rate of disagreement) through 13 (lowest rate of disagreement).

Overall, results indicated that most of the 13 Title IX compliance areas were provided for equally for women's athletic programs as compared to men's athletic programs. When collapsing the strongly agreed and agreed Likert choices, over $70 \%$ of the SWAs perceived the following 11 of the total 13 compliance areas to be provided for equally in the women's programs when compared to the men's: housing \& dining facilities $(84.4 \%)$, medical \& training facilities $(84.3 \%)$, scheduling of games $(81.1 \%)$, travel \& per diem allowances $(80.5 \%)$, practice facilities $(78.7 \%)$, competitive facilities $(78.4 \%)$, equipment and supplies $(77.7 \%)$, support services $(76.0 \%)$, tutoring $(74.3 \%)$, recruitment of student-athletes (73.2\%), and coaching (70.3\%).

When considering all 13 Title IX compliance areas, data indicated that on average when collapsing the strongly disagree and disagree categories, over $14.2 \%$ of the SWAs either strongly disagreed or disagreed that equality for women's programs were provided for equally when compared to men's programs. On the other hand, when averaging the strongly agree and agree Likert categories for all 13 of the Title IX compliance areas, data indicated that over three-fourths $(75.2 \%)$ of the SWAs either strongly agreed or agreed that women's programs were provided for equally when compared to men's.

\begin{tabular}{|l|ccccccc}
\hline \multicolumn{1}{l}{ Table 1 } \\
\multicolumn{1}{l}{ The Rank and Rates of SWA Perceptions of Equal Provision of Title IX Compliance Areas } \\
\hline Area & $\mathrm{R}$ & $\mathrm{SD}$ & $\mathrm{D}$ & $\mathrm{N}$ & $\mathrm{A}$ & SA \\
\hline publicity & 1 & 4.8 & 26.2 & 13.8 & 40.0 & 15.3 \\
locker room facilities & 2 & 6.6 & 20.5 & 9.7 & 41.3 & 21.8 \\
coaching & 3 & 3.2 & 16.8 & 9.7 & 49.2 & 21.1 \\
recruitment of student-athletes & 4 & 2.4 & 13.0 & 11.4 & 51.2 & 22.0 \\
equipment and supplies & 5 & 3.7 & 11.0 & 7.6 & 52.1 & 25.7 \\
travel \& per diem allowances & 6 & 1.9 & 10.3 & 7.4 & 49.9 & 30.6 \\
competitive facilities & 7 & 2.6 & 8.2 & 10.8 & 52.0 & 26.4 \\
scheduling of games & 8 & 1.8 & 8.9 & 8.1 & 52.8 & 28.4 \\
practice facilities & 9 & 3.2 & 7.4 & 10.8 & 52.1 & 26.6 \\
support services & 10 & 1.9 & 8.4 & 13.7 & 47.8 & 28.2 \\
medical \& training facilities & 11 & 1.9 & 6.7 & 7.2 & 50.9 & 33.3 \\
housing \& dining facilities & 12 & 1.9 & 4.8 & 9.0 & 50.1 & 34.2 \\
tutoring & 13 & 2.1 & 4.2 & 19.4 & 42.4 & 31.8 \\
\hline
\end{tabular}


Worth noting is the extent to which the SWAs strongly disagreed or disagreed that Title IX compliance areas were being provided for equally in women's programs as compared to men's. The top five areas that SWAs strongly disagreed or disagreed that women's athletic programs were being provided for equally were publicity $(31.0 \%)$, locker room facilities $(27.1 \%)$, coaching $(20.0 \%)$, recruitment of student-athletes (15.4\%), and equipment and supplies (14.7\%).

The five Title IX compliance areas that the SWAs strongly agreed or agreed, at the lowest rates, were provided for equally in their women's athletic programs were publicity $(55.3 \%)$, locker room facilities $(63.2 \%)$, coaching $(70.3 \%)$, recruitment of studentathletes $(73.2 \%)$, and tutoring $(74.3 \%)$. On the other hand, the five Title IX compliance areas that the SWAs strongly agreed or agreed were provided for equally in their women's athletic programs at the highest rates were housing \& dining facilities $(84.4 \%)$, medical \& training facilities $(84.3 \%)$, scheduling of games $(81.1 \%)$, travel \& per diem allowances $(80.5 \%)$, and practice facilities $(78.7 \%)$.

\section{Demographics}

Table 2.0 displays the SWAs by their marital status (single, married, partnered, and divorced) and the rate at which SWAs in each marital status category agreed or disagreed that the 13 Title IX compliance areas were provided for equally in the SWAs' women's athletic programs as compared to the men's athletic programs. When focusing on the SWA demographic of marital status, significant differences were found between Likert-scale items for each of the following NCAA Title IX compliance areas: equipment and supplies, scheduling of games, travel and per diem allowances, locker room facilities, practice facilities, competitive facilities, and medical and training facilities and services.

Senior Woman Administrators who were from the "divorced" marital status category strongly agreed at the highest rate of $52.6 \%$ that no less than six compliance areas were provided for equally in the women's athletic programs as compared to men's. Those compliance areas were scheduling of games, travel and per diem allowances, locker room facilities, practice facilities, competitive facilities, medical and training facilities and services, and housing and dining facilities and services.

Disagreeing or strongly disagreeing at the highest rates that the compliance area of equipment and
Table 2

Rates of SWA Perceptions of Equality of Title IX Compliance Area by SWA Marital Status

\begin{tabular}{|c|c|c|c|c|c|c|}
\hline $\begin{array}{l}\text { Compliance } \\
\text { Area }\end{array}$ & $\begin{array}{l}\text { Marital } \\
\text { Status }\end{array}$ & $\mathrm{SD}$ & $\mathrm{D}$ & $\mathrm{N}$ & A & SA \\
\hline \multirow{4}{*}{$\begin{array}{l}\text { equipment } \\
\text { and } \\
\text { supplies }\end{array}$} & Single & 3.3 & 11.8 & 12.5 & 55.9 & 16.5 \\
\hline & Married & 4.6 & 8.6 & 4.0 & 52.6 & 30.3 \\
\hline & Partnered & 0.0 & 17.7 & 5.9 & 44.1 & 32.4 \\
\hline & Divorce & 5.3 & 15.8 & 5.3 & 26.3 & 47.4 \\
\hline \multirow{4}{*}{$\begin{array}{l}\text { scheduling } \\
\text { of games }\end{array}$} & Single & 3.3 & 9.3 & 11.3 & 55.6 & 20.5 \\
\hline & Married & 1.1 & 9.1 & 5.7 & 52.6 & 31.4 \\
\hline & Partnered & 0.0 & 5.9 & 5.9 & 52.9 & 35.3 \\
\hline & Divorce & 0.0 & 5.3 & 10.5 & 31.6 & 52.6 \\
\hline \multirow{4}{*}{$\begin{array}{l}\text { travel and } \\
\text { per diem } \\
\text { allowances }\end{array}$} & Single & 2.7 & 10.7 & 11.3 & 54.7 & 20.7 \\
\hline & Married & 1.7 & 6.3 & 6.3 & 49.4 & 36.2 \\
\hline & Partnered & 0.0 & 20.6 & 0.0 & 44.1 & 35.3 \\
\hline & Divorce & 0.0 & 15.8 & 0.0 & 31.6 & 52.6 \\
\hline \multirow{4}{*}{$\begin{array}{l}\text { locker room } \\
\text { facilities }\end{array}$} & Single & 8.0 & 19.9 & 17.9 & 41.7 & 12.6 \\
\hline & Married & 5.8 & 20.1 & 4.6 & 44.3 & 25.3 \\
\hline & Partnered & 5.9 & 23.5 & 0.0 & 38.2 & 32.4 \\
\hline & Divorce & 5.3 & 21.1 & 10.5 & 15.8 & 47.4 \\
\hline \multirow{4}{*}{$\begin{array}{l}\text { practice } \\
\text { facilities }\end{array}$} & Single & 3.3 & 6.0 & 17.3 & 55.3 & 18.0 \\
\hline & Married & 2.9 & 8.0 & 6.9 & 52.0 & 30.3 \\
\hline & Partnered & 2.9 & 11.8 & 2.9 & 50.0 & 32.4 \\
\hline & Divorce & 5.3 & 5.3 & 5.3 & 31.6 & 52.6 \\
\hline \multirow{4}{*}{$\begin{array}{l}\text { competitive } \\
\text { facilities }\end{array}$} & Single & 2.7 & 4.0 & 18.1 & 57.7 & 17.5 \\
\hline & Married & 2.9 & 9.7 & 6.3 & 51.4 & 29.7 \\
\hline & Partnered & 2.9 & 14.7 & 2.9 & 44.1 & 35.3 \\
\hline & Divorce & 0.0 & 10.5 & 10.5 & 26.3 & 52.6 \\
\hline \multirow{4}{*}{$\begin{array}{l}\text { medical and } \\
\text { training } \\
\text { facilities and } \\
\text { services }\end{array}$} & Single & 2.0 & 6.8 & 10.1 & 56.8 & 24.3 \\
\hline & Married & 1.7 & 6.9 & 5.2 & 47.4 & 38.7 \\
\hline & Partnered & 3.0 & 6.1 & 6.1 & 48.5 & 36.4 \\
\hline & Divorce & 0.0 & 5.3 & 5.3 & 36.8 & 52.6 \\
\hline \multirow{4}{*}{$\begin{array}{l}\text { housing } \\
\text { and dining } \\
\text { facilities } \\
\text { and } \\
\text { services }\end{array}$} & Single & 2.0 & 6.8 & 10.1 & 56.8 & 24.3 \\
\hline & Married & 1.7 & 6.9 & 5.2 & 47.4 & 38.7 \\
\hline & Partnered & 3.0 & 6.1 & 6.1 & 48.5 & 36.4 \\
\hline & Divorce & 0.0 & 5.3 & 5.3 & 36.8 & 52.6 \\
\hline \multicolumn{7}{|c|}{$\begin{array}{c}\text { Note: } S D=\text { Strongly Disagree; } D=\overline{\text { Disagree; } N=\text { Neither Agree Nor }} \\
\text { sagree; } D=\text { Disagree; } S D=\text { Strongly Disagree. } P<.05 . \text { Marital status of } \\
\text { SWAs was: single, } 39.7 \% \text {; married, } 46.1 \% ; \text { partnered, } 8.9 \% \text {, and } \\
\text { divorced, } 5.3 \% .\end{array}$} \\
\hline
\end{tabular}

supplies was being provided for equally in women's athletic programs when compared to men's were divorced SWAs at $21.7 \%$ and partnered SWAs at $17.7 \%$. Regarding marital status, the highest rate of agreement or strong agreement that equipment and supplies was provided for equally for the women's athletic programs when compared to the men's athletic programs was held by married SWAs, at $82.9 \%$.

Scheduling games was perceived to be provided for equally in women's programs when compared to men's at a rate of $84.0 \%$ or higher by the following three marital status categories of SWAs: partnered $(88.2 \%)$, divorced $(84.2 \%)$, and married $(84.0 \%)$. Travel and per diem allowances were strongly agree or agreed to be provided for equally to the women's program by partnered and divorced SWAs. The 


\begin{tabular}{|c|c|c|c|c|c|c|c|}
\hline \multicolumn{7}{|c|}{ Rates of SWA Perceptions of Equality of Title IX Compliance Area by SWA NCAA Division } & \multirow[t]{2}{*}{ Table 3} \\
\hline Compliance Area & NCAA Division & SD & $\mathrm{D}$ & $\mathrm{N}$ & $\mathrm{A}$ & SA & \\
\hline \multirow{3}{*}{ Scheduling of games } & D-I & 1.9 & 8.3 & 8.3 & 54.6 & 26.9 & \\
\hline & D-II & 1.4 & 6.1 & 8.8 & 47.3 & 36.5 & \\
\hline & D-III & 2.5 & 12.4 & 6.6 & 57.9 & 20.7 & \\
\hline \multirow{3}{*}{ Tutoring } & D-I & 0.9 & 1.9 & 7.4 & 39.8 & 50.0 & \\
\hline & D-II & 2.8 & 3.5 & 32.4 & 35.2 & 26.2 & \\
\hline & D-III & 2.5 & 6.7 & 14.2 & 53.3 & 23.3 & \\
\hline \multirow{3}{*}{$\begin{array}{l}\text { Housing and dining facilities } \\
\text { and services }\end{array}$} & D-I & 0.0 & 1.9 & 5.8 & 51.9 & 40.4 & \\
\hline & D-II & 2.7 & 4.1 & 12.2 & 44.6 & 36.5 & \\
\hline & D-III & 2.5 & 7.4 & 7.4 & 55.4 & 27.3 & \\
\hline \multirow{3}{*}{ Publicity } & D-I & 3.7 & 33.3 & 19.4 & 32.4 & 11.1 & \\
\hline & D-II & 6.2 & 22.6 & 8.9 & 41.8 & 20.6 & \\
\hline & D-III & 4.2 & 25.0 & 14.2 & 44.2 & 12.5 & \\
\hline
\end{tabular}

highest rate of SWAs by marital status categories who strongly disagreed or disagreed that travel and per diem allowance was provided for equally to their women's athletic programs were by partnered SWAs at $20.6 \%$ and divorced SWAs at $15.8 \%$. More than one-fourth of the SWAs for each of the following marital status categories strongly disagreed or disagreed that locker room facilities were being provided for equally: partnered $(29.4 \%)$, single $(27.9 \%)$, divorced $(26.4 \%)$, and married $(25.9 \%)$.

Regardless of marital status category, in general the SWAs strongly agreed or agreed at rates between $70 \%$ and $90 \%$ that the following Title IX compliance areas were provided for equally for women's athletic programs as compared to men's athletic programs: practice facilities, competitive facilities, medical and training and services, and housing and dining facilities and services. At the high end were SWAs from the divorced category who strongly agreed or agreed at rates of $89.4 \%$, married SWAs $(86.1 \%)$ and partnered SWAs (84.9\%) that the two Title IX compliance areas of medical and training facilities and services as well as housing and dining facilities and services were provided for equally in women's programs.

Single SWAs strongly agreed or agreed at a lesser rate $(73.3 \%)$ than divorced $(84.2 \%)$, partnered $(82.4 \%)$, and married $(82.3 \%)$ SWAs that practice facilities were provided for equally in women's programs as compared to men's. Single SWAs selected "neither agreed nor disagreed" at the highest rates when compared to married, partnered, and divorced SWAs in each of the following compliance areas: equipment and supplies (12.5\%), scheduling of games $(11.3 \%)$, travel and per diem allowances $(11.3 \%)$, locker room facilities $(17.9 \%)$, practice facili- ties $(17.3 \%)$, competitive facilities $(18.1 \%)$, medical and training facilities and services $(10.1 \%)$, and housing and dining facilities and services (10.1\%).

Table 3.0 displays the SWAs by their NCAA Division (Division I, II, and III) and the rate at which SWAs in each NCAA Division agreed or disagreed that the 13 NCAA compliance areas were provided for equally in the SWAs' women's athletic programs as compared to the men's athletic programs. The SWA responses revealed a significant association between NCAA divisions and the following Title IX compliance areas: scheduling of games, tutoring, housing and dining facilities and services, and publicity.

Regarding the equal provision of publicity for women's athletics when compared to men's athletics, with respect to NCAA Division, the SWAs strongly disagreed or disagreed that women's programs were being provided for equally at the following rates: Division I (37.0\%), Division II (28.8\%), and Division III (29.2\%). The aforementioned rates of strong disagreement or disagreement were high when compared with other compliance areas in Table 3.0. Division I rates of agreement or strong agreement, pertaining to the two compliance areas of tutoring $(89.8 \%)$, and housing and dining facilities and services $(92.3 \%)$ were at least $9.6 \%$ higher than Division II and III.

Table 4.0 displays the SWAs by their years of experience $(0-5,6-10$, and $>10)$, and the rate at which SWAs in each years of experience category agreed or disagreed that the 13 NCAA compliance areas were provided for equally in the SWAs' women's athletic programs as compared to the men's athletic programs. The distribution of responses to the Title IX 


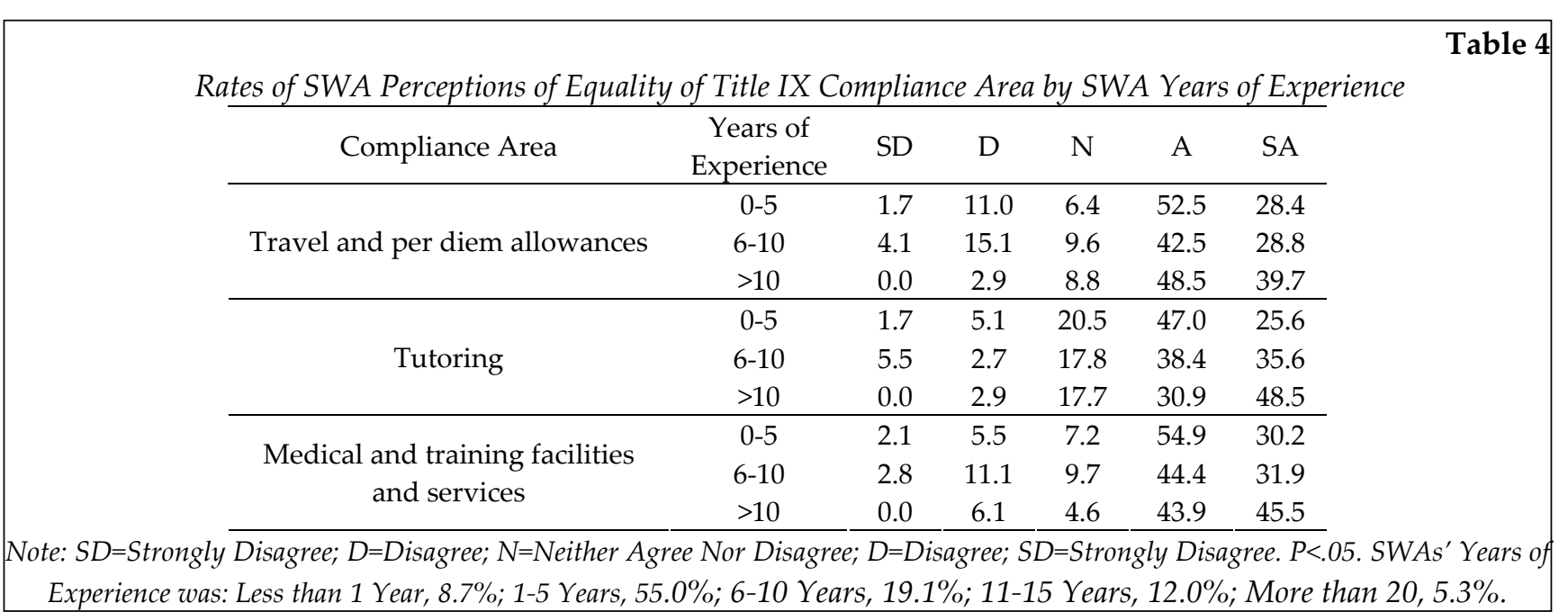

compliance areas of travel and per diem allowance, tutoring, medical and training facilities and services was found to significantly depend on the SWA demographic of years of experience.

Senior Woman Administrators with 6-10 years of experience disagreed or strongly disagreed at higher rates than SWAs with 0-5 years experience or greater than 10 years experience that travel and per diem allowances, tutoring, medical and training facilities and services were provided for equally in women's athletic programs when compared to men's. In the compliance area of medical and training facilities those SWAs with greater than 10 years experience agreed or strongly agreed at a higher rate $(89.4 \%)$ than those SWAs with $0-5$ years experience $(85.1 \%)$ and 6-10 years experience (76.3\%) that it was being provided for equally in women's programs. Those SWAs with greater than 10 years experience strongly agreed or agreed at higher rates than those SWAs with 0-5 years experience or 6-10 years of experience that travel and per diem allowance, tutoring, and medical and training facilities and services was provided for equally for women's programs as compared to men's programs.

Table 5.0 displays the SWAs by their reporting structure (president, athletic director, and "other") and the rate at which SWAs in each reporting structure category agreed or disagreed that the 13 NCAA compliance areas were provided for equally in the SWAs' women's athletic programs as compared to the men's athletic programs. When focusing on the SWA demographic of reporting structures, significant differences were found between Likert-scale items for each of the following compliance areas: practice facilities, competitive facilities, and publicity.

When compared to presidents and "other" reporting structures, SWAs who reported to athletic directors disagreed or strongly disagreed at higher rates that the following compliance areas were provided for equally in men's programs as compared to women's programs: practice facilities $(11.0 \%)$, competitive facilities $(11.5 \%)$, and publicity $(32.4 \%)$. The rates at which presidents and "other" reporting structures strongly disagreed or disagreed that practice facilities, competitive facilities, and publicity were provided for equally when compared with men's programs, were on average $12.0 \%$ lower than the perceptions of SWAs who reported to athletic directors.

Overwhelmingly agreeing or strongly agreeing that practice facilities $(100 \%)$, competitive facilities $(100 \%)$, and publicity $(85.7 \%)$ were provided for equally in women's programs as compared to men's programs were SWAs who reported to their presidents. Those SWAs who reported to athletic directors agreed or strongly agreed at lesser rates that practice facilities (77.9\%), competitive facilities $(77.0 \%)$, and publicity $(53.2 \%)$ were provided for equally in women's programs.

\section{Discussion}

\section{Overall}

The fact that when considering all 13 Title IX compliance areas $14.2 \%$ of the SWAs either strongly disagreed or disagreed that equality was provided for in women's programs when compared to men's programs is indication that there is still room for improvement. Data from this study reflects progress toward gender equity in intercollegiate athletic departments; however the goal of achieving absolute equality between women's and men's athletic programs remains. The importance of achieving absolute 
Rates of SWA Perceptions of Equality of Title IX Compliance Area by SWA Reporting Structure

Table 5

\begin{tabular}{lcccccc}
\hline Compliance Area & Reporting Structure & SD & D & N & A & SA \\
\hline \multirow{3}{*}{ practice facilities } & President & 0.0 & 0.0 & 0.0 & 42.9 & 57.1 \\
& Athletic Director & 3.2 & 7.8 & 11.2 & 53.2 & 24.7 \\
& Other & 4.4 & 0.0 & 8.7 & 43.5 & 43.5 \\
\hline \multirow{3}{*}{ competitive facilities } & President & 0.0 & 0.0 & 0.0 & 42.9 & 57.1 \\
& Athletic Director & 2.6 & 8.9 & 11.5 & 52.5 & 24.5 \\
& Other & 4.4 & 0.0 & 4.4 & 47.8 & 43.5 \\
\hline \multirow{3}{*}{ publicity } & President & 0.0 & 14.3 & 0.0 & 57.1 & 28.6 \\
& Athletic Director & 4.9 & 27.5 & 14.5 & 38.7 & 14.5 \\
& Other & 4.4 & 8.7 & 8.7 & 52.2 & 26.1 \\
\hline
\end{tabular}

Note: $S D=S t r o n g l y$ Disagree; $D=$ Disagree; N=Neither Agree Nor Disagree; $\overline{D=D i s a g r e e ;} S D=$ Strongly Disagree. P<.05. SWAs reported to: President, 1.8\%; Athletic Director, 92.1\%; and "Other," 6.1\%.

equality was also pointed out by Acosta and Carpenter (2009); and Sander (2009) who indicated that those in leadership positions must persist with strong will and resolve in the pursuit of $100 \%$ equality.

Although the overall perception of the SWAs was agreement that Title IX compliance areas were being provided for equally in women's programs as compared to men's, in the interest of reaching complete equity, several compliance areas, are still in need of attention. The areas of publicity, locker room facilities, coaching, recruitment of student-athletes, and tutoring require attention for improvement to equality for women's programs. In need of special attention/even further improvement are the compliance areas of publicity and locker room facilities.

One apparent solution to the inequitable provision of the aforementioned Title IX compliance areas simply includes increasing funds to women's programs. Reallocating funds from over provided men's programs to underprovided women's programs is another method in which the inequity gap between women's and men's programs could be further narrowed.

Regarding the Title IX compliance areas, leaders should be proactive in their plans to ensure equity between women's and men's programs. Operating budgets should be created to ensure equality between women's and men's programs in the areas of publicity, coaching, recruitment of student athletes, and tutoring. Capital budgets should address the compliance area of locker rooms. The equal provision of locker room facilities should be ensured for women's programs during the design phase of newly constructed athletic facilities and during upgrades to existing athletic facilities.

More difficult to resolve are inequities regarding publicity that are initiated and reinforced by the free market. Broadcasting networks that use their own funds to publicize university sports teams can create inequities related to publicity. If men's teams draw large television viewing audiences, the networks themselves might invest money from their company to publicize men's teams, making for an inequity unfavorable for women's teams. Decisions by directors of media outlets to broadcast selected sporting events are primarily based on the size of the viewing audience and not equality. For the purpose of achieving equality for women's programs in the area of publicity, consideration should be given to the notion of sharing portions of revenue generated from men's sports with women's sports.

\section{Demographics}

Care should be taken with regards to the generalization of results presented from the perspective of demographic characteristics related to the SWAs. Confounding variables often are of concern. Results may not necessarily be directly caused by the demographic characteristic being examined and presented. For example, in the case of the demographic of marital status, within each marital status category, confounding variables of age, personality, as well as political and religious view, etc., could also have effects on how the Title IX compliance areas are perceived.

The higher rates of disagreement from Division II and III SWAs when compared to Division I SWAs that tutoring is being provided for equally to women's programs when compared to men's programs might be the result of the potential for increased revenue generation from Division I sports over Division II and III sports. Currently, athletic departments might place a higher emphasis on tutoring for men's sports teams because of the poten- 
tial for a positive financial impact of men's basketball and football. Ensuring eligibility through tutoring may be a point of emphasis in Division I athletic departments to help generate revenue from men's basketball and football programs. Tutoring for women's teams may not receive equal emphasis because the perception exists that women's sports will not generate significant amounts of revenue.

Similarly, reasons related to the high potential for revenue generation from selected men's programs may be a reason for differences between Division I when compared to Division II and III pertaining to the area of housing and dining facilities and services. There could be an unequal/overemphasis on housing and dining facilities and services on the part of Division I men's programs when compared to women's Division I programs because of the potential for revenue generation on the part of men's basketball and football at NCAA Division I athletic departments.

Despite the fact that blatant inequalities were not revealed in the Title IX compliance areas of housing \& dining facilities, medical \& training facilities, scheduling of games, travel \& per diem allowances, and practice facilities, leaders must not assume progress toward equity will continue without effort. Institutional leaders and decision-makers, according to VanDerLinden (2004) should review existing policies and practices that may either help or hinder women. Upper administrators who carry influence over athletic departments can also assist in the pursuit of providing for women's programs equally by pursuing women vigorously for positions as interns and associate and assistant directors (Whisenant, et al., 2002). Leadership in athletic departments and beyond must continue to put forth efforts to not only maintain current progress toward gender equity as it relates to the equal provision of Title IX compliance areas toward women's and men's programs but also toward $100 \%$ achievement of equal provisions.

\section{Conclusions}

The results of this study provide athletic directors, presidents and others in intercollegiate positions of leadership with necessary information from which to base efforts and actions toward providing equally for women's and men's intercollegiate athletic programs with regards to selected areas of Title IX compliance areas. Currently, as expected, the SWAs perceived some Title IX compliance areas as being provided for more equally in women's programs as compared to men's programs.

The degree of effort necessary to achieving equality between women's and men's programs can be placed in three general categories: high priority, medium priority, and low priority. Compliance areas considered to be high priority require immediate attention for the purpose of making progress toward providing equally for women's programs when compared to men's; medium priority compliance areas require enhanced attention and low priority areas require attention not only for the purpose of maintaining equality but also for continued progress toward absolute equality.

Title IX compliance areas requiring immediate attention (high priority) are publicity, locker room facilities, and coaching. Areas requiring enhanced attention (medium priority) are the recruitment of student athletes, and tutoring. Requiring attention to maintain (low priority) and further progress toward equality are the Title IX compliance areas of housing \& dining facilities, medical \& training facilities, scheduling of games, travel \& per diem allowances, and practice facilities.

In the interest of achieving $100 \%$ equity over the long term, efforts must consistently be applied to all compliance areas. Despite general agreement by the SWAs that compliance areas were being provided for equally in women's programs as compared to men's, continued efforts must be put forth to achieve a status of complete equity between women's and men's programs.

\section{Recommendations for Future Research}

Although a prime objective of survey research is to arrive at meaningful results through data analysis of subjects' perceptions that are directly related to the survey questions, often data analysis also reveals new questions that call for future research. The following questions arose from this research study and should be considered for future research.

Without regard for demographic characteristics of the SWAs, future research should be considered to identify items not being provided for equally in women's programs when compared to men's. Specifically, further research is warranted in the compliance areas of publicity, locker room facilities, coaching, recruitment of student-athletes, and equipment and supplies.

With regard for demographic characteristics of the SWAs, future research is necessary in a variety of 
areas. Additional research is recommended to help determine why SWAs who report to presidents disagree or strongly disagree at higher rates, when compared to SWA's who report to athletic directors, that the compliance areas of practice facilities, competitive facilities, and publicity were being provided for equally in women's programs when compared to men's programs. In an effort to shed more light on differences in the perceptions of married, partnered, and divorced SWAs, additional research is needed. Further research also might be recommended to shed light on reasons why those SWAs with greater than 10 years experience generally agreed at higher rates (when compared with SWAs who had 0-5 years experience or 6-10 years experience) that compliance areas were being provided equally for women's programs as compared to men's.

\section{References}

Acosta R.V. \& Carpenter L.J. Thirty-seven years later, Title IX hasn't fixed it all. Academe, 2009; 95(4), 22-24.

Andrews-Little D. Organizational commitment of senior woman administrators. Unpublished doctoral dissertation, Florida State University, Tallahassee. Retrieved September 9, 2009; (2006) from http://etd.lib.fsu.edu/theses/submitted/etd-07092007-170225/unrestricted/Andrews-LittleDDissertation.pdf.

Cheslock J.J., Eckes S.E. Statistical evidence and compliance with Title IX. New directions for institutional research, Vol. 2008; (138), 31-45.

Dupreé J., Willis A.D., \& Pettaway K. Challenges confronting female intercollegiate athletic directors of NCAA member institutions by division. College Student Journal, 2006; 40(3), 528-545.

Gender Equity/Title IX: Important facts. (n.d.). Retrieved September 28, 2009; from: http://www1.ncaa.org/membership/ed_outreach/gender_equity/general_info/facts.html.

Kuznick L., \& Ryan M. Changing social norms? Title IX and legal activism comments from the Spring 2007; Harvard Journal of Law and Gender conference. Harvard Journal of Law and Gender, 2007; 31(2), 367-422.

Lipka S. GAO Examines Effects of Title IX. Chronicle of Higher Education, 2007; 53(47), 36.

Lipka S., \& Wolverton B. Title IX enforcement called 'deeply troubling.' Chronicle of Higher Education, 2007; 53(43), A1A34.

Marks P. Polls cast the net wider. New Scientist, 2005; 186(2497), 17-20.

NCAA Division I Manual 2008-09. Retrieved February 23, (2008) 2009; from http://www.ncaa.org.

NCAA Gender Equity Manual (n.d.). Retrieved September 26, 2009; from http://www.docstoc.com/docs/1848259/NCAA-Gender-Equity-Manual.

The National Coalition for Girls and Women in Education (2008). Title IX at 35: Beyond the headlines. Retrieved September 14, 2009; from http://www.agele.org/pdf/TitleIXat35-full\%20report.pdf.

Pittman A.T. Sport scheduling and Title IX compliance. The Journal of Physical Education \& Dance, 2007; 78(7), 8-9.

Ransdell L.B. Maximizing response rate in questionnaire research. American Journal of Health Behavior, 1996; 20(2), 5056.

Sander L. Backers of Title IX hope Obama will end 'stalemate' over enforcement. Chronicle of Higher Education, 2009; 55(24), 20.

Schachter R. Title IX turns 35. University Business, 2007; 10(3), 44-50.

Suggs W. Top posts in sports programs still tend to go to White men. The Chronicle of Higher Education. 2000; 46(39), A53-54.

Tiell B. Roles tasks and career paths of the senior woman administrator in intercollegiate athletics for Division III research. Retrieved April 21, 2005; from http://tuintranet.tiffin.edu/btiell/WLS/NCAAResearch/ SWADivisionIIIResearch/SWAEditorial.html 
U.S. Department of Labor. (n.d.). Title IX, Education Amendments of 1972. Retrieved October 3, 2009; from http://www.dol.gov/oasam/regs/statutes/titleix.htm.

U.S. Supreme Court. Grove City College v Bell, 465 US 555 (1984). Retrieved September 24, 2009; from: http://laws.findlaw.com/us/465/555.html.

Vest B. \& Masterson G. Title IX and Its Effect on Sports Programs in High School and Collegiate Athletics. Coach \& Athletic Director, 2007; 77(5), 60-62.

VanDerLinden K. Gender differences in the preparation and promotion of community college administrators. Community College Review, 2004; 31(4), 1-24.

Whisenant, W.A. How women have fared as interscholastic athletic administrators since the passage of Title IX. Sex Roles, 2003; 49(3/4), 179-184.

Whisenant W.A., Pedersen P.M., \& Obenour B.L.. Success and gender: determining the rate of advancement for intercollegiate athletic directors. Sex Roles: A Journal of Research, 2002; November.

\section{Corresponding author}

\section{Robert C. Schneider}

Department of Kinesiology, Sport Studies, and Physical Education, The College at Brockport, SUNY, 350 New Campus Drive, Brockport, NY 14420.

Work Phone: 585-395-2587;

Cell Phone: 585-423-9603

Fax: 585-395-2771;

E-mail: rschneid@brockport.edu; 